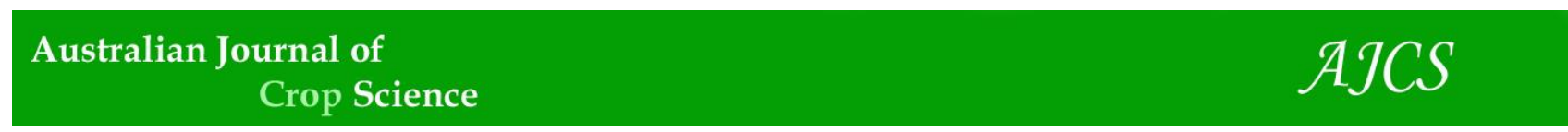

AJCS 10(8):1136-1143 (2016)

ISSN:1835-2707

DOI: $10.21475 /$ ajcs.2016.10.08.p7727

\title{
Agriculture and forest: A sustainable strategy in the Brazilian Amazon
}

\author{
Lucieta Guerreiro Martorano $^{1^{*} \text {, Marco Antonio Siviero }}{ }^{2}$, Daiana C. Monteiro Tourne ${ }^{3}$, Sabrina \\ Benmuyal Vieira $^{2}$, David R Fitzjarrald ${ }^{4}$, Carlos A. Vettorazzi ${ }^{5}$, Silvio Brienza Júnior ${ }^{1}$, Jorge Alberto \\ Gazel Yeared $^{6}$, Élio Meyering ${ }^{2}$, Leila Sheila Silva Lisboa ${ }^{7}$
}

\author{
${ }^{1}$ Embrapa Eastern Amazon, Belém, Pará, Brazil \\ ${ }^{2}$ Grupo Arboris, Dom Eliseu, Pará, Brazil \\ ${ }^{3}$ ESALQ/CENA, Piracicaba, São Paulo, Brazil \\ ${ }^{4}$ University at Albany - SUNY, Albany, New York, USA \\ ${ }^{5}$ ESALQ/USP, Piracicaba, São Paulo, Brazil \\ ${ }^{6}$ Forest Management, Head of Embrapa Amapá, Macapá, Amapá, Brazil \\ ${ }^{7}$ Sciences at ESALQ, Belém, Pará, Brazil
}

*Corresponding author: lucieta.martorano@embrapa.br

\begin{abstract}
Large-scale agriculture is increasing in anthropogenically modified areas in the Amazon Basin. Crops such as soybean, maize, oil palm, and others are being introduced to supply the world demand for food and energy. However, the current challenge is to enhance the sustainability of these areas by increasing efficiency of production chains and to improve environmental services. The Amazon Basin has experienced a paradigm shift away from the traditional slash-and-burn agricultural practices, which offers decision makers the opportunity to make innovative interventions to enhance the productivity in previously degraded areas by using trees to ecological advantage. This study describes a successful experiment integrating the production of soybean and paricá (Glycine max L. and Schizolobium amazonicum) based on previous research that indicated potential topoclimatic zones for planting paricá in the Brazilian state of Pará. This paper shows that a no-tillage system reduces the effects of drought compared to conventional tillage still used by many farmers in the region. The integrated system was implemented during the 2014/2015 season in 234.6 ha in the high-potential zone in the municipality of Ulianópolis, Pará. Both soybean and paricá were planted simultaneously. Paricá was planted in $5 \mathrm{~m} \times 2 \mathrm{~m}$ inter-tree spacing totaling $228 \times 10^{3}$ trees per hectare and soybean, in $4 \mathrm{~m} \mathrm{x} 100 \mathrm{~m}$ spacing, distributed in nine rows with a $0.45 \mathrm{~m}$ inter-row distance, occupying $80 \%$ of the area. The harvested soybean production was $3.4 \mathrm{tha}^{-1}$, higher than other soybean monocultures in eastern Pará. Paricá benefited from soybean fertilization in the first year: It exhibited rapid development in height (3.26 m) and average diameter $(3.85 \mathrm{~cm})$. Trees and crop rotation over the following years is six years for forest species and one year for each crop. Our results confirm there are alternatives to the current production systems able to diminish negative impacts resulting from monoculture. In addition, the system provided environmental services such as reduced soil erosion and increased carbon stock by soil cover with no-tillage soybean cultivation. The soybean cover contributes to increased paricá thermal regulation and lower forestry costs. We concluded that innovative interventions are important to show local farmers that it is possible to adapt an agroforest system to large-scale production, thus changing the Amazon.
\end{abstract}

Keywords: Agroforest support; paradigm shift; sustainable landscape, integrated system, decision makers.

Abreviation: BR_Belém Brasília; DBH_Diameter at Breast Height; FAO_Food and Agriculture Organization of the United Nations; IBGE_Instituto Brasileiro de Geográfia e Estatística; IMAZON_Instituto do Homem e Meio Ambiente da Amazônia; NAMAs_ National Mitigation Actions; SRTM_Shuttle Radar Topography Mission images.

\section{Introduction}

The Amazon Basin contains the world's largest contiguous rain forest; the importance of its biodiversity goes beyond Brazilian borders. Some of the most commonly discussed of the region's many challenges include the expansion of the agricultural frontier, food security, introduction of biofuels, and the need for socio-environmental services as development proceeds. According to the projections by the Food and Agriculture Organization of the United Nations, demand for food will continue to grow given the need to meet human and animal food production, estimated at around 3 billion tons by 2050 (FAO, 2009). However, crops in the Amazon Biome have been identified as a threat to the maintenance of native forest areas in the region. Ensuring the importance of the Amazon in the climate system scale effect is one of the major concerns of scientists and world governments. In Brazil, deforestation and environmental effects of monoculture agriculture are the greatest problems disturbing the Amazon. Around $20 \%$ of the deforestation in the region is attributed to governmental development programs such as the Amazon and South-Central integration program, mainly the Amazon Hub Program and the Rural Development Pilot Program (Kohlhepp, 2002). In recent decades, the additional tree loss resulted from illegal deforestation (Tollefson, 2015). 
The Brazilian government has been working to develop strategies that fulfill the commitments made in the NAMAs, especially to point out sustainability indicators in agricultural production systems in the Amazon. The adoption, monitoring, and development of practices such as no-tillage conservation agriculture (Martorano et al., 2012; Lopes et al., 2015) and integrated crop-livestock-forestry systems (Strassburg et al., 2014) are increasing due to great effort by researchers, but there is still not enough information about the large-scale planting systems, the challenges they pose, and advantages that accrue from them.

Integrated systems may include plants and animals in different spatial arrangements and densities (Gil et al., 2015). These systems are complex due to the level of land degradation, but studies have been successful in improving soil quality, in increasing carbon and biomass accumulation, and in reducing soil erosion and use of agrochemicals; thus, they show potential to renew degraded areas (Fernandes, 2011). These approaches offer the prospect of reducing environmental impacts while diversifying production (Smith et al., 2014). However, they require careful planning, in which the farmers must be involved along with other decision makers, particularly in choosing areas suitable for planning, identifying technical support needed for monitoring, and in the development of other innovative intervention strategies.

In the Amazon Basin, soybean (Glycine $\max (L$.) Merr.) cultivation has been increasing in populated areas, mainly in relatively flat terrain previously used for pasture (Domingues and Bermann, 2012). In the state of Pará, the municipalities of Paragominas, Ulianópolis, and Dom Eliseu have formed the grain "belt," which offers great possibilities for agricultural expansion, although that may be done relying on only traditional knowledge about forest resources and timber harvesting. In these municipalities, paricá (Schizolobium amazonicum var. amazonicum (Huber ex Ducke) Barneby) is a native Amazon tree commonly used in homogeneous plantations and harvested to make laminated wood, plywood, and cellulose (Marques et al., 2006; Lucena et al., 2013, Sarto et al., 2015).

In this context, we advance the idea of an integrated system intercropping soybean with paricá, which is potentially viable on a large scale using technology and modern consolidated knowledge in the Amazon. The results of this effort were shared with decision makers in a partnership among those involved in teaching, research, and private rural extension efforts.

\section{Results and Discussion}

Farmers adopted the large-scale soybean-paricá integrated system following discussions about how the method can make the land more productive (Figure 4). The soybean-paricá stages of development are shown in Figure 5. The spatial arrangement was considered suitable because machine crop treatments did not impair paricá growth. Paricá survival rate was $97.7 \%$ over 12 months. On the other hand, paricá benefited from the crop treatments mainly because of the fertilizing and weed controls. This is because the paricá leaf architecture allows light to impinge the forest soil, favoring weed growth that strangles young trees by competing for water, light, and nutrients (Lunz et al., 2012).

Compared to traditional methods, weed control also represented zero additional cost over paricá cultural treatments in the first year, i.e., herbicide use decreased by $1.08 \mathrm{t} . h a^{-1}$, which will be applied in three plantation cleaning operations. In addition, since both species belong to the legume family, they have great potential to maintain and improve soil fertility, owing to nitrogen fixation through symbiosis with Proteobacteria (family Rhizobiaceae; Baral et al., 2016). Thus, the system brings economic and environmental gains for farms as well as the agroecosystem. The soybean harvest productivity was $3.4 \mathrm{t}_{\mathrm{ha}} \mathrm{h}^{-1}$. We found (Table 2) that our result is above the estimated national average (CONAB, 2016) and the average of other Amazon municipalities (Alves et al., 2014; Schwade et al., 2015). That confirms the appropriate management positively impacts productivity and that even conventional soybean can achieve high yields in an agroforest system. The integrated system is an opportunity for the state of Pará to increase productivity because, while it is the second state with the largest planted soybean area in the Amazon, it is the fourth in grain yields (Figure 6).

We hope to increase productivity even further because our system strengthens the use of grain production under no-tillage in preparation for the next harvest. Previous studies have already confirmed the environmental advantages of this agricultural practice, such as maintaining organic matter and soil moisture, reducing rainfall erosivity, soil erosion and water evaporation, and increasing soil biological activity (Freitas and Landers, 2014; Martorano et al., 2012). Following harvest, the system was replaced by corn-paricá. The forest species was 12 months old at this time.

The summary statistics for paricá plot measurements can be seen in Table 3. In 12 months, we found that $80 \%$ of the trees had around $3.5 \mathrm{~cm}-4.0 \mathrm{~cm}$ of DBH and height between $3.0 \mathrm{~m}$ - $3.5 \mathrm{~m}$ (Figure 7). The dominant trees had $4.1 \mathrm{~cm}$ mean diameter and $3.8 \mathrm{~m}$ mean height. This corroborates Marques (1990), who found similar diameter and height values in a system that integrated paricá, corn, and Brachiaria brizantha at 12 months, higher than in paricá monoculture. In monoculture, paricá had $2.95 \mathrm{~cm}$ diameter and $2.76 \mathrm{~m}$ height while in the agroforestry consortium, paricá had $4.20 \mathrm{~cm}$ diameter and 3.21 $\mathrm{m}$ height. Cordeiro et al. (2015) also confirm paricá grows larger when planted with crop species.

We could also observe the variability, quartiles, and symmetry of DBH and total tree height data per plot using boxplot graphs (Figure 8 and Figure 9). Both graphs illustrate the variation among plots. That means the sample was statistically representative of data variability. We observed the highest value from 1 to 6 plots (mean DBH: $4.5 \mathrm{~cm}$ to $5.0 \mathrm{~cm}$; mean height: $4.0 \mathrm{~m}$ to $4.5 \mathrm{~m}$ ); three plots had DBH and height values above the mean (DBH: $3.85 \mathrm{~cm}$; height: $3.26 \mathrm{~m}$ ), and the others were highly variable according to the dispersion rectangle. Thus, the distribution of both diameter and height was asymmetric in all plots.

The variation in early paricá growth can be explained by several factors. Genetics: The seeds were of unknown origin and studies have shown that the variation in progeny influences growth (Ohashi et al., 2010). This is a problem when the genetic materials are not selected for planting. Management: The planting sequence is an important factor that could have influenced growth results. The trees were planted in a west-to-east orientation. Thus, the first plots were planted first. Climate: The area's topoclimate was identified as suitable according to paricá zoning, but it is important to keep in mind the small scale of that study ( $3 \mathrm{~km} \times 3 \mathrm{~km})$, i.e., microclimatic conditions are influenced by topography and this limits zoning, such as the amount of radiant energy and temperature (Monteiro, 2013).

Other important factors concern the soil. The area features three kinds of soil clay (low, medium, and high) and medium Cation Exchange Capacity (CEC) after liming. The low CEC limited cation and water retention. The soil water deficit, for example, is the principal condition that affects paricá growth by reducing the vegetative vigor of the species (Monteiro, 
Table 1. Crop treatment applied to paricá planting rows.

\begin{tabular}{|c|c|}
\hline Treatment & Description \\
\hline Subsoiling & Operation performed with a subsoiler with a stem to dig $50 \mathrm{~cm}$ into soil; \\
\hline Basic fertilization & $\begin{array}{l}\text { Operation performed with a subsoiler applying approximately } 300 \mathrm{~g} \mathrm{hole}^{-1} \text { of } \mathrm{N}: \mathrm{P}: \mathrm{K} \text { at a ratio } \\
\text { of } 2: 30: 10\left(2 \% \mathrm{~N} ; 30 \% \mathrm{P} 2 \mathrm{O} 5 ; 10 \% \mathrm{~K}_{2} \mathrm{O}\right), 10 \text { to } 30 \mathrm{~cm} \text { deep; }\end{array}$ \\
\hline Surface nitrogen fertilization & $\begin{array}{l}\text { Application of } 200 \mathrm{~kg} \mathrm{ha}^{-1} \text { or } 200 \mathrm{~g} \text { hole } \mathrm{e}^{-1} \text { of ammonium sulphate }\left(\left(\mathrm{NH}_{4}\right) 2 \mathrm{SO}_{4}\right) \text {. This treatment } \\
\text { was performed } 45 \text { days after planting the paricá; }\end{array}$ \\
\hline Biological input & $\begin{array}{l}\text { Application of approximately } 10 \mathrm{~g}^{-1} \mathrm{e}^{-1} \text { of mycorrhizal fungi (cultivated in clay }+ \text { sand), on } \\
\text { the three seeds in each hole, to associate roots with the fungus. }\end{array}$ \\
\hline
\end{tabular}

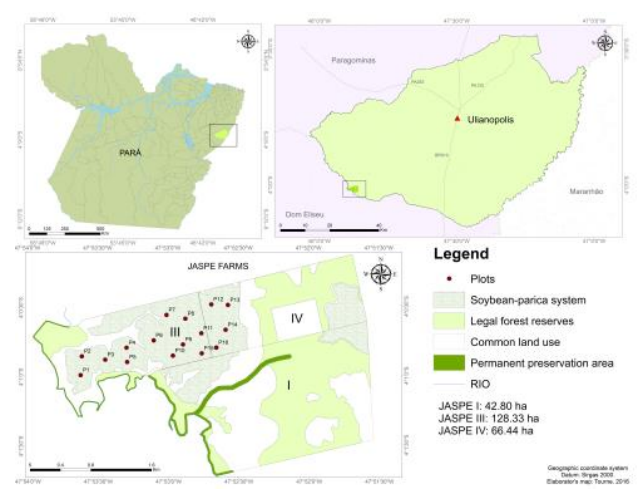

Fig 1. Study area and monitoring plots.

Table 2. Productivity of soybean in the Amazon.

\begin{tabular}{lll}
\hline Productivity $\left(\right.$ t.ha $\left.^{-1}\right)$ & Municipality & References \\
\hline 3.0 & Brazil & CONAB (2016) \\
\hline 2.8 & Paragominas-PA & Alves et al. (2014) \\
\hline 2.9 & Santarém-PA & Schwade et al. (2015) \\
\hline 2.4 & Belterra-PA & Oliveira et al. (2013) \\
\hline 3.0 & Rendenção-PA & Husny et al. (2003) \\
\hline 2.7 & Tartarugalzinho-AP & Yokomizo (2012) \\
\hline
\end{tabular}

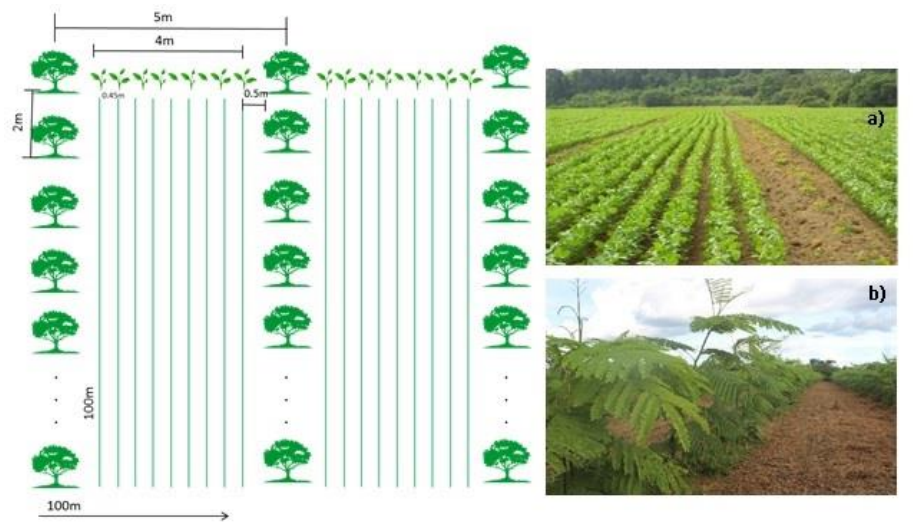

Fig 2. Distribution of soybean-paricá integrated system. a) 20 days after emergence; b) 130 days after emergence and post soybean harvest.

2013). Topography associated with region is important. We identified differences in terrain in the area through contour lines with SRTM images (Figure 10) and found that the plots with the greatest DBH and total height results were in the lowest, flattest areas. These areas had already been marked by land use differences; soil organic matter commonly varies and is often concentrated in the lower areas in anthropogenically modified soil and by the strong rains in the Amazon.

One of the goals in an integrated system is to reduce the variation in growth. The continuous adoption of no-tillage systems can add to nutrient stocks, soil organic matter, resistance to water and wind erosion, increase the diversity of the microbial population, and add to overall resilience (Vezzani and Mielniczuk, 2009), which leads to a positive result for the growth of both the crop and the trees.

\section{Materials and Methods}

\section{Study area}

The study was conducted in the farms Jaspes I, III and IV located in the municipality of Ulianópolis in southeast Pará 
Table 3. Data summary, DBH = diameter at breast height, Height $=$ total DBH of all trees per sample plot, QMD = quadratic mean diameter, Hdom $=$ height of the tallest tree per sample plot, DBHdom = mean diameter of dominant trees, $\mathrm{DBHrange}=\mathrm{DBH}$ difference of the thickest and thinnest trees per sample plot, Hrange $=$ height difference of the tallest and shortest trees per plot computed using the programming language $\mathrm{R}$.

\begin{tabular}{ll}
\hline Variables & Statistics [Mean \pm std.] \\
\hline Number of sample plots & 16 \\
Number of trees & 469 \\
DBH $(\mathrm{cm})$ & $3.85 \pm 0.75$ \\
Height $(\mathrm{m})$ & $3.27 \pm 0.60$ \\
QMD $(\mathrm{cm})$ & $3.95 \pm 1.98$ \\
DBHDom $(\mathrm{cm})$ & $4.1 \pm 0.62$ \\
Hdom $(\mathrm{m})$ & $3.8 \pm 0.50$ \\
DBHrange $(\mathrm{cm})$ & 5.6 \\
Hrange $(\mathrm{m})$ & 4.1 \\
\hline
\end{tabular}

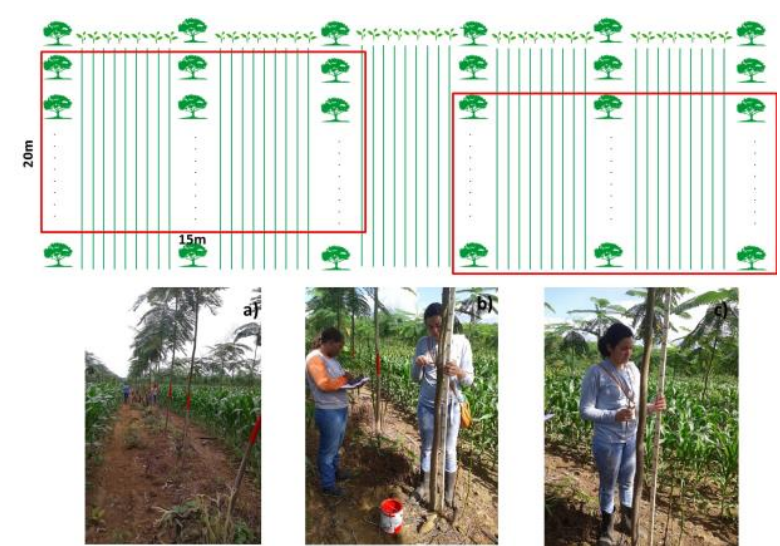

Fig 3. Monitoring plots. (a) Installation of permanent plots; (b) measurement of the diameter at breast height (DBH); (c) measurement of total tree height.

(Figure 1). Ulianópolis has tropical weather, with average temperature of $26.6^{\circ} \mathrm{C}$ and average annual rainfall of 1,961 $\mathrm{mm}$ at an average altitude of $175 \mathrm{~m}$. This municipality is part of the growing Amazon soybean belt, mainly export-oriented agricultural production. These soybean areas often replaced pasturelands (Gollnow and Lakes, 2014). The anthropogenic area in Ulianópolis is greater than $60 \%$ of the municipality $\left(3,483.5 \mathrm{~km}^{2}\right)$ (PRODES, 2014). This expansion was influenced by a historical process of population growth along roadway BR010 followed by unmanaged wood extraction and subsequent cattle ranching. Tourne et al. (2015) suggest that silviculture is a good option to promote recovery and reintegration of these areas as productive systems. They noted that more than $85 \%$ of the municipality has great potential for planting paricá.

\section{Species and plantation description}

Schizolobium parahyba var. amazonicum (paricá) is a tree native to the Amazon that is part of the legume family (Fabaceae). In Brazil, it occurs between $100 \mathrm{~m}$ and $400 \mathrm{~m}$ elevation with overall latitude ranging from $0^{\circ}$ to $13^{\circ} \mathrm{S}$. The species is a shadeintolerant tree and copes with mean temperature from 24.7 to $27.0{ }^{\circ} \mathrm{C}$ and water deficit up to $270 \mathrm{~mm}$ (Monteiro, 2013). Its planted area has been increasing over the past 10 years. Harvesting paricá every six to seven years can achieve productivity from 30 to $35 \mathrm{~m}^{3} \cdot \mathrm{ha}^{-1} \cdot \mathrm{yr}^{-1}$ in homogeneous plantation (Vidaurre et al., 2012). Soybean (Glycine max (L.) Merr.) belongs to the legume family (Fabaceae) and is one of the most cultivated crops worldwide (118.1 million hectares), with approximately 33.6 million ha planted in the USA and 31.5 million ha in Brazil (EMBRAPA, 2015). USA, Brazil, and China are responsible for $86 \%$ of the worldwide production (He and Chen, 2013).
Soybean is used for oil and protein production, generating revenues of US\$ 17.71 billion for Brazil (MAPA, 2015).

The soybean-paricá integrated system, designed ultimately to be commercial, was an innovative intervention of a farm subsidized by research from Embrapa Eastern Amazon (the Brazilian Agricultural Research Enterprise) and collaborators. The system was implemented from January $15^{\text {th }}$ to February $10^{\text {th }} 2015$ in 228 hectares of land belonging to the Arboris Group, located in an area with great potential for planting paricá following earlier topo-climatic studies (Martorano et al., 2011) and paricá zoning (Monteiro, 2013; Tourne et al., 2015). Soybean was planted following conventional practices (Dalmago et al., 2010; Bamberg et al., 2012). Plowing, harrowing, and application of limestone (2 tons per hectare) were carried out according to recommendations obtained from pedological diagnosis by a laboratory of MT Solos Análises Agronômicas S/C Ltda in Dom Eliseu, Pará.

The sampling design is simple to install and monitor over time (Figure 2). Paricá was planted in $5 \mathrm{~m} \mathrm{x} 2 \mathrm{~m}$ inter-tree spacing, totaling $228 \times 10^{3}$ trees per hectare. Before that, the seeds were automatically scarified near the seed coat and dipped in clean water at room temperature to break dormancy. Three seeds were planted about $4 \mathrm{~cm}$ deep $30 \mathrm{~cm}$ away from the other seeds in each hole. We also applied crop treatment to the soil, including subsoiling, basic fertilization, nitrogen fertilization, biological application with fungi (Siviero et al., 2008), and herbicide during paricá planting (Table 1).

Soybean (cultivar ANsc 93101) was planted with $4 \mathrm{~m} \times 100$ $\mathrm{m}$ spacing, distributed in nine rows and $0.45 \mathrm{~m}$ inter-row distance within the paricá crop. The cultivar is a new variety of conventional soybean widely used in the region due to its high productivity. In this arrangement, soybean occupied $80 \%$ of the total area (186.4 ha). Seeds were inoculated with fungus and bacteria, following recommendations by Pereira et al. 


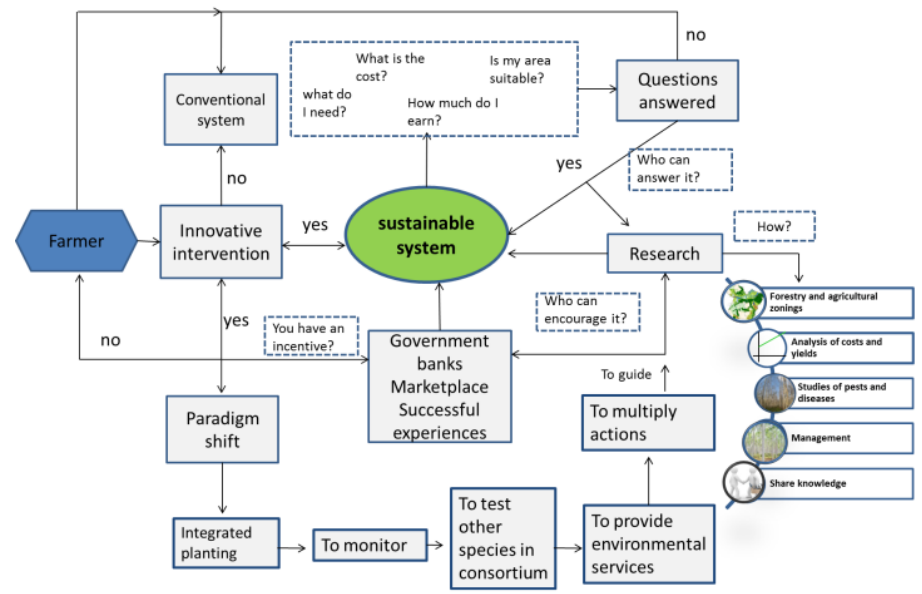

Fig 4. Strategic planning developed in this applied research.

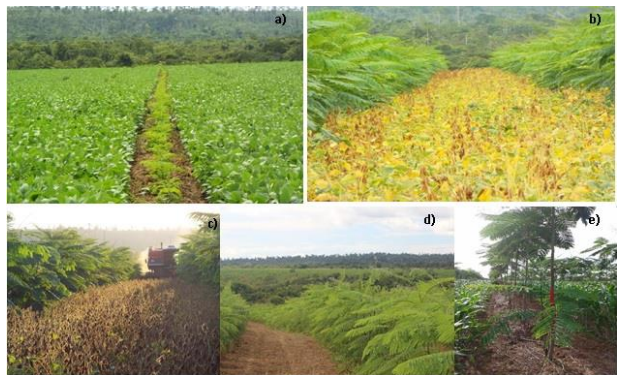

Fig 5. Growth and development of soybean-paricá. (a) 30 days; (b) 120 days; (c) 130 days; (d) 5 months; (e) 12 months after emergence.

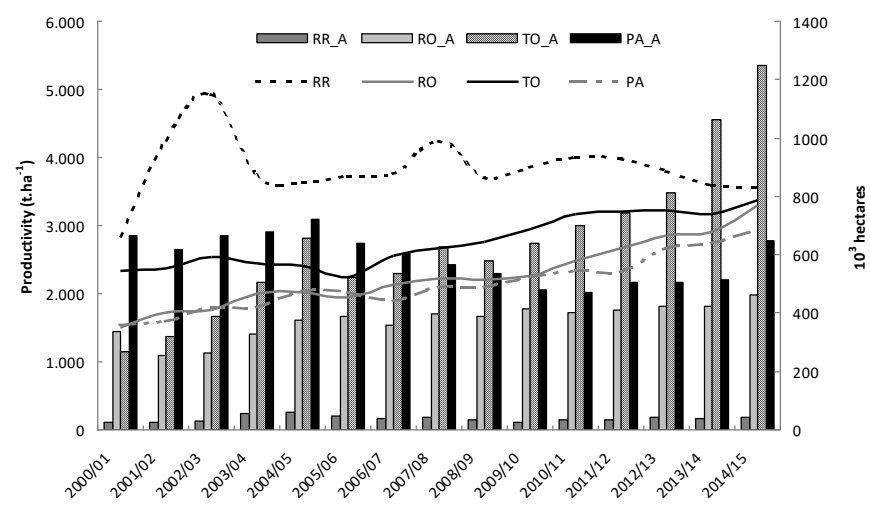

Fig 6. Soybean productivity and planted area in four states of the Amazon.
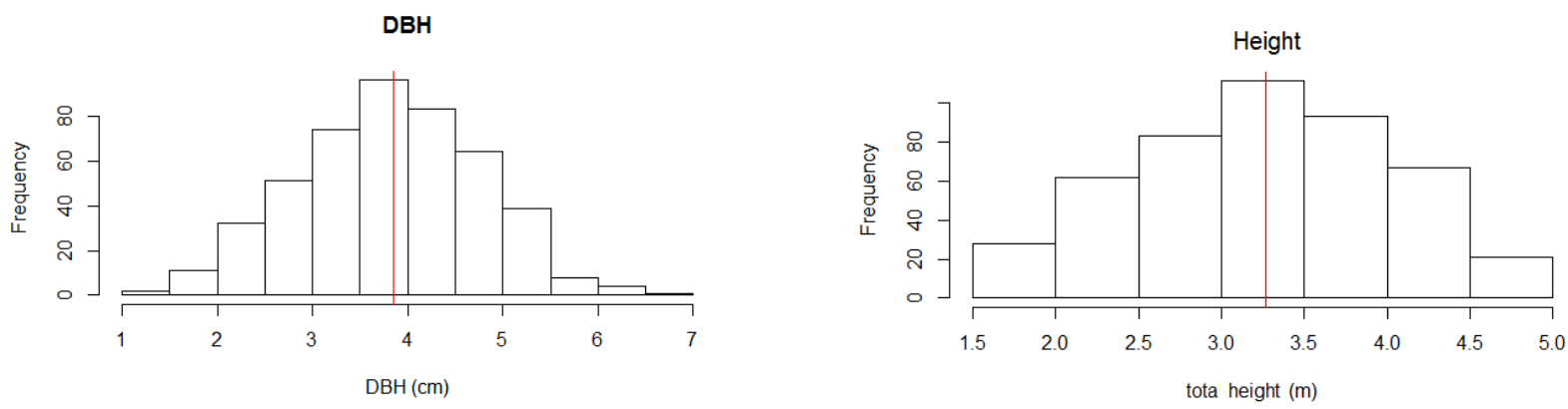

Fig 7. DBH and Height frequency distribution of paricá with 12 months per total sample. 


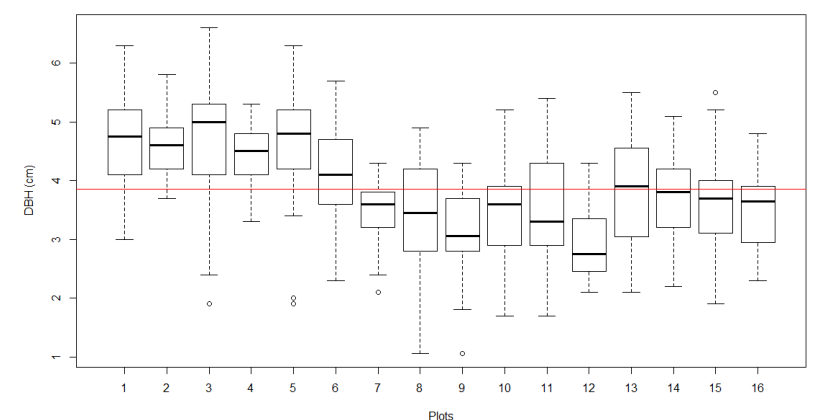

Fig 8. Boxplot of paricá DBH per plot with 12 months in the soybean-paricá integrated system. The red line represents the general mean of the data.

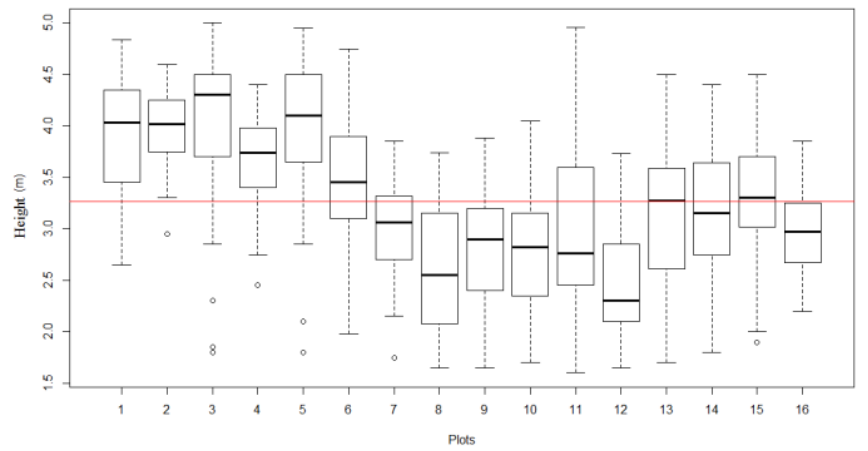

Fig 9. Box plot of paricá total height per plots with 12 months in the soybean-paricá integrated system. The red line represents the general mean of the data.

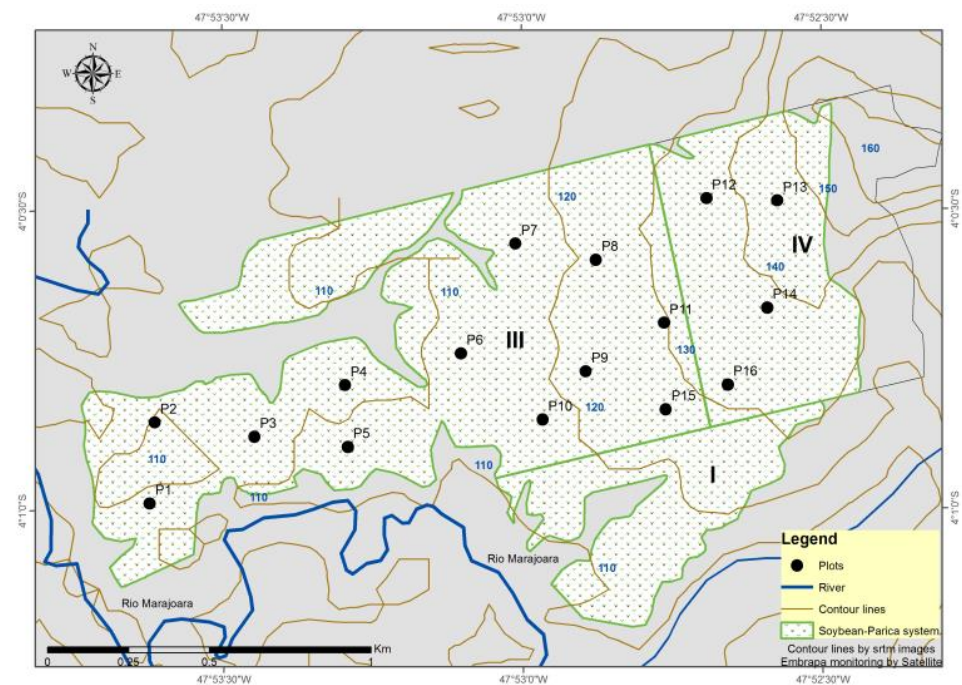

Fig 10. Contour map of the planting area in Jaspe I, III, and IV farms Ulianópolis, Pará, Brazilian. Amazon.

(2010) and Araújo et al. (2012). The inoculation was done up to 72 hours before sowing to maintain seed viability. Soybean sowing was performed along with nitrogen $(\mathrm{N})$, phosphorus $(\mathrm{P})$, and potassium $(\mathrm{K})$ fertilization at a ratio of 02-25-25. Weed species were controlled by a systemic herbicide, plus adjuvant, diluted in water in post-emergence. We followed fertilization and cultural methodological practices guidelines set in the Southern Soybean Research Meeting (Oliveira et al., 2014).

\section{Monitoring plots}

Forest monitoring units were installed in 16 permanent plots $\left(15 \mathrm{~m} \times 20 \mathrm{~m}\right.$ ), representing $4,800 \mathrm{~m}^{2}$ (Figure 3). The sample units (plots) were randomly distributed with a distance of 15 hectares from one another. Dendrometric data of \pm 30 trees one year after planting were collected at each plot. The DBH was sampled with a caliper with precision of $1 \mathrm{~mm}$ while height was measured with a $2.20 \mathrm{~m}$ stick graduated every $10 \mathrm{~cm}$. We also considered a distance of at least $20 \mathrm{~m}$ from road and reserve boundaries to avoid border effects. All plots were georeferenced and individuals were marked with red paint for the next monitoring. Soybean was harvested mechanically after 130 days and the productivity data was computed.

\section{Data analysis}

Mean soybean productivity was compared with other monocultures elsewhere in Pará. Paricá growth data, including DBH and total tree height, were organized and analyzed by measures of dispersion to verify amplitude, standard deviation, and variability. The growth of dominant 
trees was calculated using the mean height and diameter of the ten largest trees in each plot. Afterwards, we applied descriptive statistics of position and shape to describe the most important characteristics of the data, as well as to interpret both numeric and graphic information. The descriptive measures used were mean, median, quartiles, symmetry, data distribution by histogram, identification of outliers, and maximum and minimum values by boxplot diagram. We also verified data normality by the ShapiroWilk method.

\section{Strategic plan development}

We have been working with assistance to rural producers to change traditional agriculture paradigms in the Amazon. To this end, we developed strategies to achieve a sustainable system and a successful experience based on research experience and strategic planning guidelines (World Bank, 2001). As the first step, the producer must agree to the strategic planning to allow us to share our research results with entrepreneurs, using a participatory approach methodology. In the meetings, we discussed the potential of an integrated system, environmental implications, cost, space, time, research application, and motivation. Next, we also used topoclimatic information and topoclimatic zones to guide the choice of appropriate area for planting. Next, with the experimental design and arrangement installed, the producer and researchers could monitor the growth and assess the advantages of the more sustainable integrated production system. It was a strategy to subsidize the producer and to democratize the knowledge generated by research in the Amazon.

\section{Conclusion}

The results presented in this study clearly show that the agroforestry system is a form of land use that led to economic and environmental gain over one experimental year. The strategic planning for planting crops and trees in an integrated system is sufficient to recover anthropogenically modified areas. This approach offers a way to alter landscapes, change the current agricultural approaches, inform decision makers, and offer a pathway for the continuous adoption of such systems on a large scale. Zoning studies for crop and forest species are an immediate need to select areas with potential for planting, and, consequently, to increase agricultural safety and wood production in a low-carbon economy in the Amazon. The soybean-paricá system was an example of successful and innovative experience in the region. We present the results of a successful interaction among teachers, researchers, extension agents, and entrepreneurs. The methodology has great potential to be replicated and to stimulate interest among other farms in the Amazon and in the world, expanding rural social opportunities while promoting sustainability.

\section{Acknowledgements}

The authors would like to thank the Brazilian Agricultural Research Enterprise (EMBRAPA), the University of São Paulo (ESALQ/USP), the São Paulo Research Foundation (FAPESP), the State University of Pará (UEPA), and the Federal Rural University of the Amazon (UFRA). We thank all farmers and their technicians involved, who made these results possible. We highly appreciate the support of Arboris Group for the confidence, partnership, and desire for changes.

\section{References}

Alves LWR, Carvalho EJM, Silva LGT (2014) Diagnóstico agrícola do município de Paragominas, Pa. Boletim de Pesquisa e Desenvolvimento 91, Belém, 26 p.

Araújo FG, Rocha MR, Aguiar RA, Garcia RA, Cunha MG (2012) Management of soybean rust with fungicides for seed treatment and foliar application. Semina: Ciências Agrárias. 33(1):2585-2592.

Bamberg AL, Martinazzo R, Silveira CAP, Madaloz LM, Fernandes A (2012) Infiltração de água em planossolo háplico cultivado com soja (Glicine max. L.) em sistema de preparo convencional e plantio direto. Paper presented at the XIX Reunião Brasileira de Manejo e Conservação do Solo e da Água, Universidade do Estado de Santa Catariana, Lages, 29 jul-03 ago de 2012.

Baral B, Silvab JAT, Izaguirre-Mayoralc ML (2016) Early signaling, synthesis, transport and metabolism of ureides. J Plant Physiol. 193:97-106.

CONAB (2016) Companhia Nacional de Abastecimenro. In: Levantamento de safra brasileira de grãos, safra 2015/16, quinto levantamento, 182 p. Available in: http://www.conab.gov.br/OlalaCMS/uploads/arquivos/16_0 3_11_15_20_36_boletim_graos_marco_2016.pdf

Cordeiro IMCC, Barros PLC, Lameira OA, Gazel Filho AB (2015) Avaliação de plantios de paricá (Schizolobum parahyba var. amazonicum (Huber ex Ducke) Barneby de diferentes idades e sistemas de cultivo no município de aurora do Pará - Pa (Brasil). Cienc Florest. 25(3): 679-687.

Dalmago GA, Bergamaschi H, Krüger CAMB, Bergonci JI, Comiran F, Heckler BMM (2010) Evaporação da água na superfície do solo em sistemas de plantio direto e preparo convencional. Pesq Agropec Bras. 45(8):780-790.

Domingues MS, Bermann C (2012) O arco de desflorestamento na Amazônia: da pecuária à soja. Ambient Soc. 15(2): 1-22.

Husny JC, Andrade EB, Almeida LA, Klepker D, Meyer MC (2003) BRS Tracajá: cultivar de soja para a região Sul do Pará. Comunicado técnico 83, Belém, 5 p.

EMBRAPA (2015) Empresa Brasileira de Pesquisa Agropecuária (Embrapa Soja). In: Soja em números. Available

https://www.embrapa.br/soja/cultivos/soja1/dadoseconomicos.

FAO (2009) Food and Agriculture Organization of the United Nation. In: High Level Expert Forum - How to Feed the World in 2050 - Global agriculture towards 2050. Available http://www.fao.org/fileadmin/templates/wsfs/docs/Issues_p apers/HLEF2050_Global_Agriculture.pdf.

He FJ, Chen JQ (2013) Consumption of soybean, soy foods, soy isoflavones and breast cancer incidence: Differences between Chinese women and women in Western countries and possible mechanisms. Food Sci and Human Wellness. 2(3-4):146-161.

Fernandes PCC (2011) Integrated crop-livestock-forest systems in the amazon: demands of environmental, social and economic development. Advances in Animal Biosciences, Addendum: Session 3. 1(2):1.

Gollnow Fl, Lakes T (2014) Policy change, land use, and agriculture: The case of soy production and cattle ranching in Brazil, 2001-2012. Appl Geogr. 55:203-211.

Freitas PL, Landers JN (2014) The transformation of agriculture in brazil through development and adoption of zero tillage conservation agriculture. International Soil and Water Conservation Research. 2(1):35-46. 
Gil J, Siebold M, Berger T (2015) Adoption and development of integrated crop-livestock-forestry systems in Mato Grosso, Brazil. Agr Ecosyst \& Environment. 199:394-406.

Kohlhepp G (2002) Conflitos de interesse no ordenamento territorial da Amazônia brasileira. Estud Av. 16(45):37-61.

Lopes ELN, Fernandes AR, Teixeira RA, Sousa ES, Ruivo MLP (2015) Soil attributes under different crop management systems in an Amazon Oxisols. Bragantia. 74(4):428-435.

Lucena VB, Raimam MP, Cardoso NA, Albino UB (2013) Influência de fungos micorrízicos-arbusculares em paricá (Schizolobium amazonicum) cultivado no estado do Pará. Pesq Flor Bras. 33(75):235-241.

Lunz AM, Azevedo R, Júnior MCMO, Monteiro OM (2012) Recomendações para o Monitoramento de Cigarras [Quesada gigas (Olivier), Hemiptera: Cicadidae] em Reflorestamentos com Paricá [Schizolobium parahyba var. amazonicum (Huber ex Ducke) Barneby]. Circular técnica 46, Belém, 12 p.

Marques LCT (1990) Comportamento inicial de parícá, tata juba e eucalipto, em plantio consorciado com milho e capim-marandu, em Paragominas, Pará. Dissertação (Mestrado em Ciências Florestais) - Universidade Federal de Viçosa, 73 f, Minas Gerais.

Marques LCT, Yared JAG, Siviero MA (2006) A evolução do conhecimento sobre o paricá para reflorestamento no Estado do Pará. Comunicado técnico 158, Belém, 5 p.

Martorano LG, Bergamaschi H, Faria RT, Dalmago GA (2012) Decision strategies for soil water estimations in soybean crops subjected to no-tillage and conventional systems, in brazil. In techopen: Problems, Perspectives and Challenges of Agricultural Water Management. http://cdn.intechopen.com/pdfs-wm/31515.pdf.

Martorano LG, Monteiro DCA, Brienza Junior B, Lisboa LSS, Espirito Santo JM do, Almeida RF (2011) Topbioclimate conditions associated with the natural occurrence of two Amazonian tree species for sustainable reforestation in the State of Para, Brazil. WIT Transactions on Ecol Envir. 144:111-122.

MAPA (2015) Ministério da Agricultura, Pecuária e Abastecimento. In: Produção de soja 2015. Available in http://www.brasil.gov.br/economia-eemprego/2015/09/producao-de-soja-se-aproxima-de-100milhoes-de-toneladas.

Monteiro DCA (2013) Condições Topoclimáticas preferenciais para plantios de Paricá (Schizolobium parahyba var. amazonicum (Huber ex. Ducke Barneby) e evidências de desempenho para otimizar a silvicultura em áreas desflorestadas na Amazônia. Dissertação (Mestrado em Ciências/ Ecologia Aplicada) - Escola Superior de Agricultura "Luiz de Queiroz"/Cena, 153 f, Piracicaba.

Ohashi ST, Yared JAG, Farias Neto JT (2010) Variabilidade entre procedências de paricá Schizolobium parahyba var amazonicum (Huber ex Ducke) Barneby plantadas no município de Colares - Pará. Acta Amaz.40(1):81-88.

Oliveira JA, Leite RMVBC, Castro C (2014) Reunião de pesquisa de soja. Resumos expandidos presented at the XXXIV Reunião de Pesquisa de Soja, Embrapa, Londrina, 14-15 agost de 2014. 292 p.

Pereira CE, Oliveira JA, Caldeira CM, Botelho FJE (2010) Effect of treating seeds with fungicides and storage on the response of plants inoculated with Bradyrhizobium. Rev Agroambiente. 4(2):62-66.

PRODES (2014) Monitoramento da Floresta Amazônica Brasileira por Satélite. In: Taxas de desmatamento da Amazônia Legal. Disponível em: http://www.dpi.inpe.br/prodesdigital/prodesmunicipal.php.
Sarto C, Segura TES, Silva-Junior FGS (2015) Performance of Schizolobium amazonicum wood in bleached kraft pulp production. Bioresourses. 10(3):4026-4037.

Schwade S, Gallo J, Oliveira Júnior RC, Oliveira DR, Melem Júnior NJ, Santos DB (2015) Avaliação da produtividade da soja sob diferentes doses de fósforo na região de Santarém - PA. In: XXXV Congresso Brasileiro de Ciência do Solo: O solo e suas mútiplas funções. 2-7 de agosto de 2015.

Siviero MA, Motta AM, Lima DS, Birolli RR, Huh SY, Santinoni IA, Murate LS, Castro CMA, Miyauchi MYH, Zangaro W, Nogueira MA, Andrade G (2008) Interaction among $\mathrm{N}$-fixing bacteria and AM fungi in Amazonian legume tree (Schizolobium amazonicum) in field conditions. Appl Soil Ecol. 39:144-152.

Smith P, Bustamante M, Ahammad H, Clark H, Dong H, Elsiddig EA, Haberl H, Harper R, House J, Jafari M, Masera O, Mbow C, Ravindranath NH, Rice CW, Robledo Abad C, Romanovskaya A, Sperling F, Tubiello F (2014) Agriculture, Forestry and Other Land Use (AFOLU). In: Climate Change 2014: Mitigation of Climate Change. Contribution of Working Group III to the Fifth Assessment Report of the Intergovernmental Panel on Climate Change. Cambridge University Press, Cambridge, United Kingdom and New York, NY, USA.

Strassburg BBN, Latawiec AE, Barioni LG, Nobre CA, Silva VP, Valentim JF, Vianna M, Assad ED (2014) When enough should be enough: Improving the use of current agricultural lands could meet production demands and spare natural habitats in Brazil. Global Environ Chang. 28:84-97.

Tollefson J (2015) Battle for the Amazon. Nature 520:20-23.

Tourne DCM, Martorano LG, Brienza Junior S, Dias CTS, Lisboa LS, Sartorio SD, Vettorazzi C A (2015) Potential topoclimatic zones as support for forest plantation in the Amazon: Advances and challenges to growing Paricá (Schizolobium amazonicum). Environmental Development. $10 \mathrm{p}$.

Vezzani FM, Mielniczuk J (2009) Uma visão sobre qualidade do solo. Rev Bras Cien Solo, 33(4): 743-755.

Vidaurre GB, Carneiro ACOC, Vital BR, Santos RC, Valle MLA (2012) Propriedades energéticas da madeira e do carvão de paricá (Schizolobium amazonicum). Rev Árvore. 36(2):365371.

Yokomizo GKI (2012) Produtividade da soja na região do município de Tartarugalzinho - AP. Comunicado técnico 147, Macapá, 5 p. 